\title{
Renal Hemorrhage
}

National Cancer Institute

\section{Source}

National Cancer Institute. Renal Hemorrhage. NCI Thesaurus. Code C78594.

Bleeding originating from the kidney. 